\title{
Mature trees versus seedlings: Differences in leaf traits and gas exchange patterns in three co-occurring Mediterranean oaks
}

\author{
Sonia MEDIAVILlA*, Alfonso ESCUDERO \\ Departamento de Ecología, Facultad de Biología, Universidad de Salamanca, 37071 Salamanca, Spain
}

(Received 19 February 2002; accepted 1 August 2002)

\begin{abstract}
We studied gas-exchange patterns and leaf traits of seedlings and mature trees of three coexisting Mediterranean oaks with contrasting leaf habits (the evergreen Quercus ilex, and the deciduous $Q$. faginea and $Q$. pyrenaica) during the well-watered part of the growth season. Leaf life span in $Q$. ilex seedlings was shorter than in mature trees, whereas for the deciduous species the differences in leaf life span between both growth stages were less pronounced. In all species leaves on seedlings displayed a lower mass per unit area and lower nitrogen content than on mature trees. However, owing to their larger stomatal conductance, leaves on seedlings usually showed larger photosynthetic nitrogen-use efficiency and lower water-use efficiency than on mature trees. Stomatal conductance and $\mathrm{CO}_{2}$ assimilation rate were lower in $Q$. ilex than in the two deciduous species at the mature stage. However, the interspecific differences in gas exchange rates related to differences in leaf longevity disappeared at the seedling stage because in $Q$. ilex the seedlings showed a much higher stomatal conductance than the adults. Thus, seedlings of the three species showed a common strategy, regardless of the leaf life span, probably as a response to the competition from the herbaceous layer.
\end{abstract}

growth stages / leaf gas-exchange / leaf traits / Quercus sp.

Résumé - Arbres adultes versus semis : différences de caractéristiques foliaires des types d'échanges gazeux chez trois espèces coexistantes de Quercus. Les échanges gazeux et les caractéristiques foliaires des semis et des arbres adultes de trois espèces coexistantes de chênes méditerranéens présentant des caractéristiques foliaires contrastées (une espèce à feuille persistante Quercus ilex et deux espèces à feuille caduque $Q$. faginea et $Q$. pyrenaica) ont été étudiés lors des phases les plus favorables de la saison de croissance. La longévité foliaire des semis a été inférieure à celle des adultes pour $Q$. ilex et similaire pour les deux autres espèces. Les feuilles des semis ont un poids plus faible par unité de surface et une moindre teneur en azote que celle des adultes. Cependant, à cause de leur plus forte conductance stomatique, les semis ont montré une meilleure efficience d'utilisation de l'azote dans la photosynthèse et une plus faible efficience d'utilisation de l'eau que les arbres adultes. La conductance stomatique et l'assimilation de $\mathrm{CO}_{2}$ ont été plus faibles pour $Q$. ilex par rapport aux deux autres espèces à l'état adulte. Cependant, les différences interspécifiques dans les échanges gazeux ont disparu au stade semis, et les semis de $Q$. ilex ont présenté une conductance stomatique beaucoup plus forte que les arbres adultes. Les plantules de trois espèces ont donc présenté une stratégie commune, indépendamment de leur longévité foliaire, vraisemblablement en réponse à la concurrence de la strate herbacée.

stades de croissance / échanges gazeux foliaires / caractéristiques foliaires / Quercus sp.

\section{INTRODUCTION}

Seedling establishment and juvenile growth are critical periods in the life cycle of tree species [20], and the morphological and physiological leaf attributes during these periods are key factors for recruitment and survival of tree populations. Furthermore, many aspects of leaf morphology and physiology may vary with tree age $[11,28]$. Comparative studies of different growth stages may provide essential information for understanding the strategies adopted by the species at different stages of their life cycle, as well as the selective pressures that operate in each stage.
Differences in the development of the root system between adults and seedlings result in differences in water availability and in water use strategies [9, 31, 32]. For this reason, most studies comparing seedlings and adults in woody species have mainly focussed on the analysis of the water relations and on the effect of water stress on patterns of gas exchange and mortality during the two developmental stages [3-5, 14-16]. Less emphasis has been placed on the comparison of the patterns of leaf gas-exchange of seedlings and adults during the part of the growth season free of drought stress. The patterns of gas exchange in spring can also be of great importance for seedling survival because they determine the

*Corresponding author: ecomedv@usal.es 
amount of photosynthates available for the development of the root system. Moreover, transpiration during spring partly controls subsequent soil water availability.

In this study we analysed the leaf traits and patterns of gasexchange during the well-watered part of the growth season in mature trees and seedlings of three co-occurring Quercus species. Very few comparative studies $[3,5,16]$ have been made on seedlings and mature specimens of oaks growing in the field under similar conditions. And, to our knowledge, none of these has been made in Mediterranean climates, where the short duration of the growth season [22] lends special relevance to the gas-exchange rates obtained during the short favourable season.

Our objective was to find out whether the strategies of gasexchange and photosynthetic resource-use in the more favourable part of the growth season differed between seedlings and adults and to analyse the relationships between leaf traits and gas exchange at the two stages. Strong relationships between leaf $\mathrm{N}$ content and gas exchange rates have frequently been observed when comparing species with different leaf longevities $[18,26]$. Usually species with longer leaf life span display lower leaf $\mathrm{N}$ contents and gas exchange rates [25, 27]. However, the relationships between $\mathrm{N}$ content and photosynthesis can be affected by compromises between maximising carbon gain and water conservation [19]. We predicted that the leaves of seedlings in Mediterranean climates should maintain a less conservative water use strategy than the adults, owing to the need to compete for soil water resources with the herbaceous layer, and that this should contribute to reduce the interspecific differences in gas exchange rates related to differences in leaf longevity at seedling stage.

\section{MATERIALS AND METHODS}

\subsection{Study species and area}

The study was carried out during three years (1995-1997) on adult trees and seedlings of the evergreen species Quercus ilex L. subsp. ballota (Desf.) Samp. (= Quercus rotundifolia Lam.) and the deciduous species $Q$. faginea Lam. and $Q$. pyrenaica Willd. All species were growing in five plots located close to the city of Salamanca, in central-western Spain, between latitudes $41^{\circ} 10^{\prime} \mathrm{N}$ and $40^{\circ} 50^{\prime} \mathrm{N}$ and longitudes $6^{\circ} 35^{\prime} \mathrm{W}$ and $5^{\circ} 40^{\prime} \mathrm{W}$. Altitudes ranged between $\approx 750$ and $900 \mathrm{~m}$ above sea level. Quercus ilex L. subsp. ballota is characteristic of the interior of the Iberian Peninsula, where climate is more severe than close to coasts. The two deciduous species predominate in the regions with milder or oceanic climates [29]. However, the three species coexist in large areas of the interior Iberian Peninsula and were present in each of the selected plots.

Three plots consisted of sparse populations (about 50 trees ha ${ }^{-1}$ ) of isolated mature trees over 100 years old with open pasture areas among them. Such savannah-like formations ("dehesas") are very frequent in the western part of the Iberian Peninsula. Trunk diameter at $1.3 \mathrm{~m}$ height ranged from 20 to $60 \mathrm{~cm}$ and mean heights were about 6-10 m. Seedlings were studied in the two other plots, planted at a density of $1000 \mathrm{ha}^{-1}$. Plantation was carried out during November prior to the first year of our study with seedlings obtained from acorns collected in areas close to the studied stands, and which were grown in a nursery during one year. During the last growth season (four years of age) the height of the seedlings was around $40-60 \mathrm{~cm}$, whereas the maximum diameter of the trunk varied between $7-10 \mathrm{~mm}$ for the two deciduous species and 4-6 mm for Q. ilex. The two planted plots were frequently subjected to weed control.

The soils, distric cambisol in all cases, are poor in organic matter and in nutrients, with a low $\mathrm{pH}$ and medium/low water retention capacity. Clay content ranges between 17 and 24\%; silt, 14-16\% and sand between $61-64 \%$. The climate is cold Mediterranean, with a mean annual temperature between 11 and $13{ }^{\circ} \mathrm{C}$. Annual precipitation ranges between $400-650 \mathrm{~mm}$, of which approximately $20-25 \%$ usually corresponds to spring (data provided by the National Institute of Meteorology, Valladolid Centre). Rainfall is scarce during the months of July and August, and summer drought occurs every year.

\subsection{Gas-exchange measurements}

Gas-exchange measurements were carried out in the field, during late spring and early summer (before the onset of drought). Measurements were taken from 7.00 to 10.00 a.m. (solar time), thus avoiding the time of the day with heat stress. The $\mathrm{CO}_{2}$ assimilation figures may thus be regarded as an estimate of the maximum assimilation rate of each leaf type. Measurements were taken weekly on completely expanded leaves at mid height in the canopy. The leaves from seedlings and adults received full sunlight during the measurement period. On adult trees, leaves were selected on three or four individuals of each species in each plot. In seedlings, however, the number of individuals selected in each species in each plot was increased to 10, owing to the greater variability between individuals observed during this growth stage. Approximately 40 leaves of each type were included in the final estimates of photosynthetic capacity for adult trees and around 80 samples of each leaf type in seedlings. In the evergreen species the two age-classes present in the crown were studied.

The measurements were taken with a portable photosynthesis system (LI-6200, Li-Cor Inc., Lincoln, NE, US) at ambient $\mathrm{CO}_{2}$ concentration (around $360 \mu \mathrm{L} \cdot \mathrm{L}^{-1}$ ), air temperatures between 20 and $35^{\circ} \mathrm{C}$, relative humidities between $20-50 \%$ and saturating photosynthetic photon flux density (above $\approx 800 \mu \mathrm{mol} \mathrm{m}^{-2} \mathrm{~s}^{-1}$ ). All leaves were collected and taken to the laboratory for subsequent processing.

\subsection{Sample processing and variables estimated}

After gas-exchange measurements, leaf area (Delta-T Image Analysis System, Delta-T Devices Ltd., Cambridge, UK), dry weight (after drying at $60^{\circ} \mathrm{C}$ until constant weight) and $\mathrm{N}$ concentration (CEInstruments NA-2100 autoanalyzer, ThermoQuest, Milan, Italy) were measured. Leaf mass per unit area (LMA), $\mathrm{N}$ concentration per unit mass $\left(\mathrm{N}_{\text {mass }}\right), \mathrm{N}$ concentration per unit area $\left(\mathrm{N}_{\text {area }}\right), \mathrm{CO}_{2}$ assimilation per unit mass $\left(\mathrm{A}_{\text {mass }}\right), \mathrm{CO}_{2}$ assimilation per unit area $\left(\mathrm{A}_{\text {area }}\right)$ and instantaneous nitrogen-use efficiency (PNUE), as the ratio between $A_{\text {area }}$ and $\mathrm{N}_{\text {area }}$, were derived from these data. The $\mathrm{A}_{\text {area }} / \mathrm{g}$ ratio (assimilation per unit area/stomatal conductance) was taken as an estimate of water use efficiency for a given vapour pressure deficit (intrinsic water-use efficiency)

In order to calculate leaf life span in the adults, sampling of branches with leaves from different crown positions of each canopy was performed on 4 specimens of each species selected at random in each plot at monthly intervals over 3 years of study. The samples were immediately taken to the laboratory and separated into shoots of different classes. Sub-samples of 40-50 shoots were used to calculate the average number of leaves per shoot in each month and for each age-class. In the seedlings, at monthly intervals over the three years of study we estimated the total number of leaves of each age-class present in the crown in 10 specimens selected for each species in each plot. The different leaf cohorts produced within a year were distinguished by marking with coloured wires. The mean number of leaves per shoot of a given age on each census date were used to elaborate life tables, which made it possible to calculate the mean life span for 
the leaves of each species according to the standard methods [2]. Maximum leaf life span was estimated with the same procedure but using only $25 \%$ of the initial leaf cohort with a higher persistence. For seedlings the data obtained were averaged for the different leaf cohorts produced within a year.

\subsection{Statistical analyses}

For analysis of the data we used the SPSS statistical package (SPSS Inc., Chicago, IL). Two-way analysis of variance and Fisher's protected LSD test were used to establish significant difference at $P \leq$ 0.05 between means after applying the Levene test to check for homogeneity of variances.

\section{RESULTS}

\subsection{Leaf characteristics: interspecific comparisons and tree age-related differences}

Patterns of leaf emergence varied between seedlings and mature trees. In seedlings there were several flushes of leaf emergence, hence the total leaf biomass per tree increased gradually during spring (Fig. 1). In mature trees there was only one flush at the beginning of the growth season so that the maximal leaf biomass was reached rapidly. In $Q$. ilex seedlings a severe mortality was observed in the leaves during the autumn-winter immediately after their emergence. Thus, mean leaf life span was only about 9 months in $Q$. ilex seedlings versus almost 2 years in adult trees (Tab. I). By contrast, in $Q$. faginea seedlings many leaves were retained green until following spring (Fig. 1). Consequently, the mean leaf life span of $Q$. faginea seedlings was larger than that of mature trees by approximately one month (Tab. I). For $Q$. pyrenaica seedlings the mean leaf life span was, on average, approximately one month less than that of adults.

In all cases, leaf mass per unit area (LMA) and leaf nitrogen content were significantly lower in seedlings than in mature trees, although the differences in $\mathrm{N}$ content between seedlings and adults were less intense in $Q$. ilex than in the deciduous species (Fig. 2). Within each growth stage, there were significant interspecific differences in LMA. Highest values were reached in leaves of the evergreen species, and among these in one-year-old leaves (Fig. 2). Nitrogen content per unit leaf mass $\left(\mathrm{N}_{\text {mass }}\right)$ was significantly larger in the deciduous species than in $Q$. ilex, both in adults and in seedlings (Fig. 2), although the interspecific differences were less intense among seedlings. With respect to the nitrogen content per unit area $\left(\mathrm{N}_{\text {area }}\right)$, there were no significant differences between the current-year leaves of the adults of the three species. In contrast, in the seedlings $Q$. ilex reached a significantly higher average $\mathrm{N}_{\text {area }}$ than the deciduous species (Fig. 2).

\subsection{Leaf gas-exchange: interspecific comparisons and tree age-related differences}

Maximum daily stomatal conductance was higher on average in $Q$. ilex and $Q$. faginea seedlings than in the mature trees of the same species, particularly in the case of $Q$. ilex (Fig. 3). In $Q$. pyrenaica, however, maximum conductance was almost
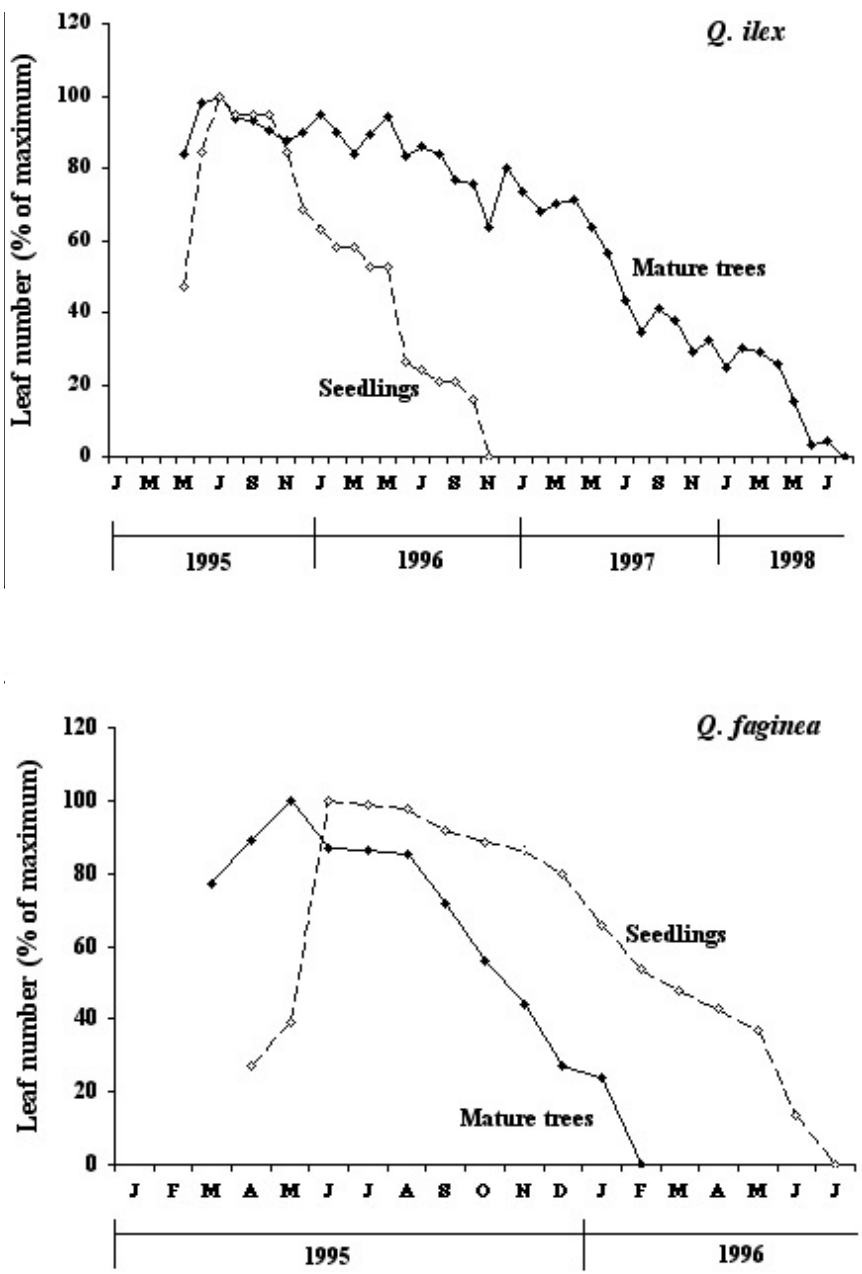

Figure 1. Some examples of leaf survivorship curves in seedlings and mature trees of $Q$. ilex and Q. faginea.

Table I. Mean and maximum (age at $25 \%$ survivorship) leaf longevity of the species studied.

\begin{tabular}{lccc}
\hline Species & $\begin{array}{c}\text { Growth } \\
\text { stage }\end{array}$ & $\begin{array}{c}\text { Mean leaf } \\
\text { longevity (days) }\end{array}$ & $\begin{array}{c}\text { Maximum leaf } \\
\text { longevity (days) }\end{array}$ \\
\hline Q. ilex & trees & 723 & 1140 \\
Q. ilex & seedlings & 275 & 573 \\
Q. faginea & trees & 204 & 315 \\
Q. faginea & seedlings & 229 & 397 \\
Q. pyrenaica & trees & 160 & 258 \\
Q. pyrenaica & seedlings & 124 & 213 \\
\hline
\end{tabular}

identical for both growth stages. In contrast, the seedlings of the two deciduous species maintained significantly lower $\mathrm{CO}_{2}$ assimilation values per unit leaf area $\left(\mathrm{A}_{\text {area }}\right)$ than their counterparts from mature trees. Similarly, despite the high stomatal conductance they exhibited, the assimilation rates of the $Q$. ilex seedlings were similar to those of the mature trees 


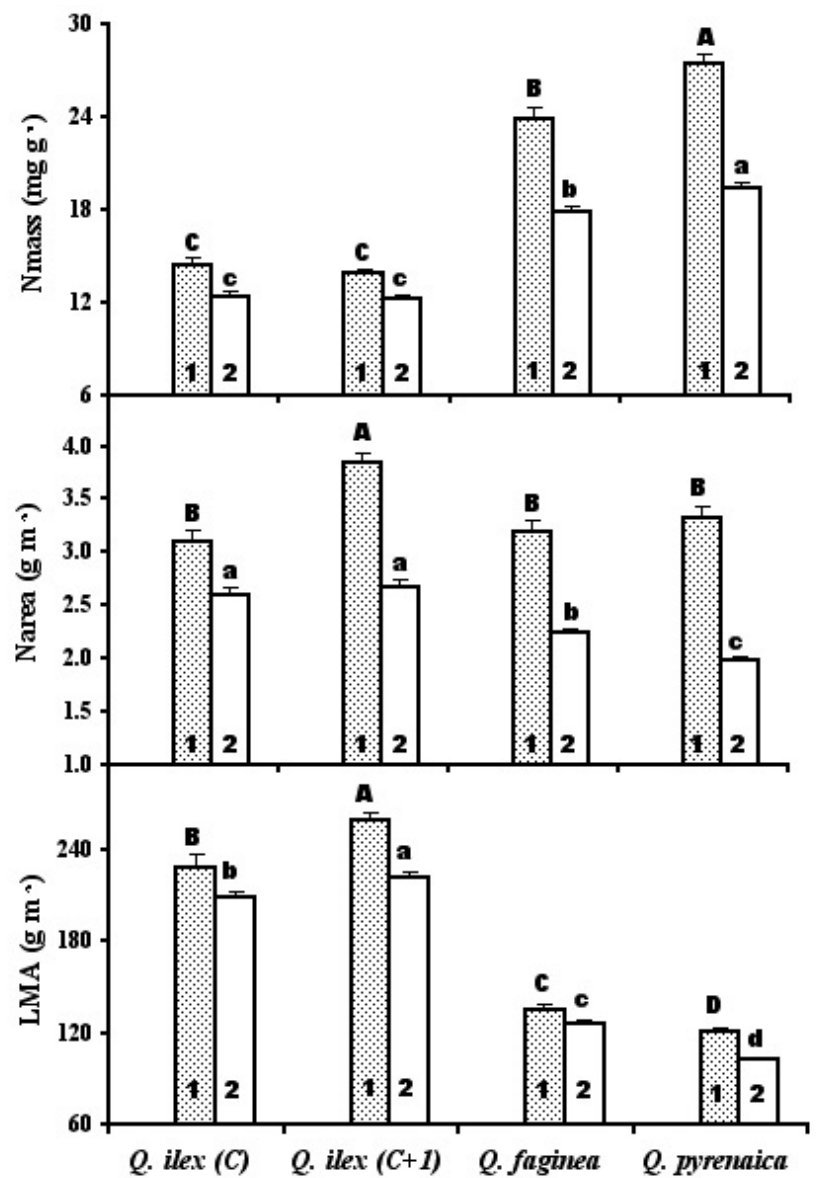

Figure 2. Mean $( \pm$ S.E.) leaf mass per unit area (LMA) and leaf $N$ concentration per unit area (Narea) and per unit mass (Nmass) in mature trees (dotted bars, $n=40$ ) and in seedlings (open bars, $n=80$ ). For each leaf type different numbers within the bars indicate significant differences $(P<0.05)$ between adults and seedlings. Dotted bars with different uppercase letters above indicate significant differences $(P<0.05)$ among leaf types for mature trees. Open bars with different lowercase letters above indicate significant differences $(P<0.05)$ among leaf types for seedlings. In $Q$. ilex current- $(\mathrm{C})$ and 1-year-old $(\mathrm{C}+1)$ leaves are included.

(Fig. 3). Thus, intrinsic water-use efficiency $\left(\mathrm{A}_{\text {area }} / g\right)$ was in all cases significantly lower in the seedlings than in the adults (Fig. 4). In contrast, photosynthetic nitrogen-use efficiency was significantly higher in the younger trees in $Q$. ilex and $Q$. faginea, and not significantly different between seedlings and adult trees in $Q$. pyrenaica (Fig. 4). Finally, the assimilation rate per unit leaf mass $\left(\mathrm{A}_{\text {mass }}\right)$ did not reflect a general trend in the comparisons between growth stages (Fig. 3).

Among mature trees, the evergreen species displayed on average lower $\mathrm{CO}_{2}$ assimilation rates, both per unit leaf area and per unit leaf mass, and lower stomatal conductance than deciduous ones (Fig. 3). In the seedlings also Q. pyrenaica showed the highest stomatal conductance. However, hardly any difference was observed between the conductance values obtained in $Q$. ilex and $Q$. faginea. The leaves of $Q$. faginea

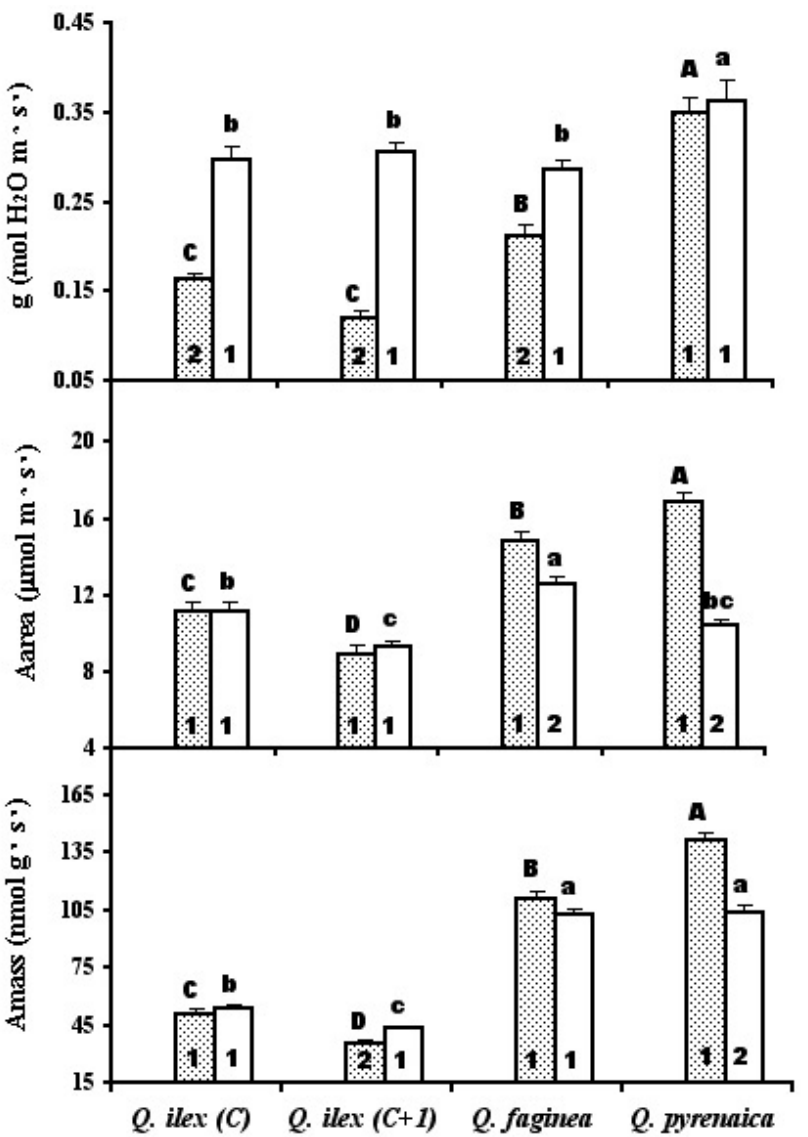

Figure 3. Mean ( \pm S.E. $)$ maximum stomatal conductance $(\mathrm{g})$ and $\mathrm{CO}_{2}$ assimilation rate per unit area (Aarea) and per unit mass (Amass) in mature trees (dotted bars, $n=40$ ) and in seedlings (open bars, $n=80$ ). For each leaf type different numbers within the bars indicate significant differences $(P<0.05)$ between adults and seedlings. Dotted bars with different uppercase letters above indicate significant differences $(P<0.05)$ among leaf types for mature trees. Open bars with different lowercase letters above indicate significant differences $(P<0.05)$ among leaf types for seedlings. In $Q$. ilex current- $(\mathrm{C})$ and 1-year-old $(\mathrm{C}+1)$ leaves are included.

seedlings displayed largest $\mathrm{CO}_{2}$ assimilation rates per unit area. Among the other leaf types, the differences were not significant (Fig. 3). On the contrary, $A_{\text {mass }}$ values were similar in the two deciduous species and significantly higher in them than in Q. ilex (Fig. 3).

Mean intrinsic water-use efficiency was similar in mature $Q$. ilex and $Q$. faginea trees and significantly lower in Q. pyrenaica (Fig. 4). In the seedlings, however, A/g was similar in $Q$. ilex and $Q$. pyrenaica, and significantly lower in both cases than in $Q$. faginea. Finally, the photosynthetic nitrogenuse efficiency in the mature trees was significantly different for all the leaf types, with the highest values corresponding to $Q$. pyrenaica and the lowest to $Q$. ilex (Fig. 4). In the seedlings, however, although once again $Q$. ilex showed lower PNUE, the differences did not reach significance in the two deciduous species (Fig. 4). 


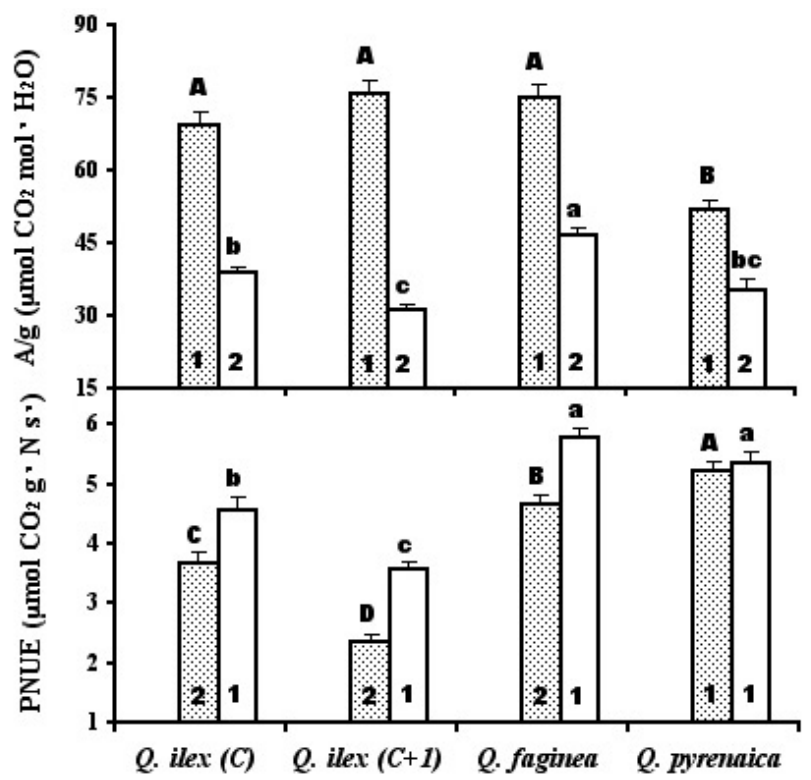

Figure 4. Mean $( \pm$ S.E.) intrinsic water use efficiency (Aarea/g) and photosyntetic nitrogen use efficiency (PNUE) in mature trees (dotted bars, $n=40$ ) and in seedlings (open bars, $n=80$ ). For each leaf type different numbers within the bars indicate significant differences $(P<0.05)$ between adults and seedlings. Dotted bars with different uppercase letters above indicate significant differences $(P<0.05)$ among leaf types for mature trees. Open bars with different lowercase letters above indicate significant differences $(P<0.05)$ among leaf types for seedlings. In $Q$. ilex current- $(\mathrm{C})$ and 1-year-old $(\mathrm{C}+1)$ leaves are included.

\section{DISCUSSION}

Significant morphological and physiological differences were observed between leaves of mature trees and seedlings. One problem associated with the approach used in this study is the possible genetic differences between mature specimens and the seedlings used in the afforestation, which could evidently contribute to the physiological and morphological differences between growth stages. In addition, transplanting stress can affect the physiological performance of the seedlings for some time after plantation. However, the differences observed in the present study between the two growth stages were so large that it is unlikely that they arose only from the above-mentioned possible artefacts. Within a growth stage, the differences between different stands were not significant (data not shown) and the interspecific comparisons yielded similar results in all stands. There is no reason to expect that genetic distance between the seedlings and the adults will be higher than between the adult specimens studied in the different plots. Finally, transplanting stress should especially affect the results obtained during the first year of the study. However, the results obtained this first year could not be distinguished from those obtained during the remainder of the study period (data not shown).

Mature trees exhibited larger LMA, larger leaf $\mathrm{N}$ content and lower maximum stomatal conductance than the seedlings, as other authors have also observed in several oak species
$[1,5,16,17,28]$. However, the extent of the difference between growth stages varied among the three species studied, as suggested by the significant interaction term in the two-way ANOVA found for most of the variables (data not shown). $Q$. ilex was the species for which the most pronounced differences in stomatal conductance between growth stages were obtained. As a consequence, in the seedlings the interspecific differences differed from those we and many other authors have observed in mature trees. Thus, in the mature trees, a lower stomatal conductance and assimilation rate was associated with a longer leaf life span, greater LMA and smaller $\mathrm{N}_{\text {mass }}$, as several authors have reported [21, 25, 27]. By contrast, among the seedlings, neither the interspecific differences in the maximum stomatal conductance nor in the photosynthetic rates can be fully explained by the leaf life span, although PNUE was still clearly lower in $Q$. ilex seedlings than in the two deciduous species, owing to the effects associated with the greater LMA [23].

In principle, this result might be attributed to the relatively small interspecific differences in the mean leaf life span in seedlings in comparison with the mature trees, mainly because of the short leaf life span of the $Q$. ilex seedlings. However, the maximum leaf life span was still greater in $Q$. ilex seedlings than in the deciduous species (Tab. I), which seems to indicate that the leaves of $Q$. ilex seedlings are also designed to reach a greater life span than those of the two deciduous species. Indeed, $Q$. ilex seedlings, in comparison with the deciduous species, continued to exhibit traits proper to a species of longer leaf life span, such as smaller $\mathrm{N}_{\text {mass }}$ and greater LMA.

The seedlings of the three species apparently tend to maximise their stomatal conductance under favourable conditions, despite the fact that such high conductance resulted in very low water-use efficiency during the early stages of development (Fig. 4), as other authors have also observed in different species $[5,14,15]$. Taking into account that water shortage is a strong limiting factor in our regions with Mediterranean climate, how then can we explain the strategy shown by the seedlings and the differences with respect to the more conservative water use strategy of the adults?

Probably the peculiarities of the ecophysiology of the seedlings are a response to the intense competition for soil water they usually have to cope with, both from herbaceous vegetation and from other trees [7, 10]. Oaks have rapid root growth and produce deep taproots as seedlings [8, 30]. However, it may take some years to pass the maximum penetration depth of the roots of the herbaceous plants and thus reduce their competitive effects ([3,31], Mediavilla, personal observation). Maintaining high water-use efficiency through strong stomatal control would imply lower net $\mathrm{CO}_{2}$ assimilation rates and, therefore, a reduction in growth. Furthermore, conservation of the soil water reserves would increase the availability of soil water for potential competitors [6, 12]. A low water-use efficiency in benefit of an increase in growth and a strong allocation to the root biomass would probably be a more successful strategy under the competitive conditions that the seedlings experience during their establishment [13].

In short, our results reveal that the strong physiological interspecific differences at leaf level in the adults related to differences in leaf life span tend to decrease and even disappear 
at the seedling stage. Some authors [24] postulate important differences in total production and growth between seedlings of species that differ in leaf life span, which, nevertheless, are thought to attenuate during the adult stage because of the accumulation of several leaf cohorts in the species with longer leaf life span. However, in our case it seems that the interspecific differences in leaf life span show a smaller effect on the physiological differences at leaf level in seedlings than in mature trees, and this should contribute to reduce the differences in growth rate between species differing in leaf longevity. Continuing research in this field in order to analyse the effects of leaf traits on the growth rate of seedlings of different species and to determine in which stage of the ontogeny of the different species the maturing of the physiological traits of the leaves occurs could provide very useful information for clarifying the relations of competition between the different species.

Acknowledgements: This paper has received financial support from the Spanish Ministry of Education (Projects No. FOR89-0845 and AMB95-0800) and from the Junta de Castilla y León (Projects No. SA47/95 and SA72/00B). We thank two anonymous reviewers for helpful comments on the manuscript.

\section{REFERENCES}

[1] Acherar M., Rambal S., Comparative water relations of four Mediterranean oak species, Vegetatio 99/100 (1992) 177-184.

[2] Begon M., Harper J.L., Townsend C.R., Ecology. Individuals, Populations and Communities, Blackwell Science, Oxford, 1996.

[3] Bragg W.K., Knapp A.K., Briggs J.M., Comparative water relations of seedling and adult Quercus species during gallery forest expansion in tallgrass prairie, For. Ecol. Manage. 56 (1993) 29-41.

[4] Brown J.R., Archer S., Water relations of a perennial grass and seedlings vs adult woody plants in a subtropical savanna, Texas, Oikos 57 (1990) 366-374.

[5] Cavender-Bares J., Bazzaz F.A., Changes in drought response strategies with ontogeny in Quercus rubra: implications for scaling from seedlings to mature trees, Oecologia 124 (2000) 8-18.

[6] Cohen D., The expected efficiency of water utilization in plants under different competition and selection regimes, Isr. J. Bot. 19 (1970) 50-54

[7] Collet C., Guehl J.M., Frochot H., Ferhi A., Effect of two forest grasses differing in their growth dynamics on the water relations and the growth of Quercus petraea seedlings, Can. J. Bot. 74 (1996) $1562-1571$.

[8] Danner B.T., Knapp A.K., Growth dynamics of oak seedlings (Quercus macrocarpa Michx. and Quercus muhlenbergii Engelm.) from gallery forests: implications for forest expansion into grasslands, Trees 15 (2001) 271-277.

[9] Davis S.D., Mooney H.A., Tissue water relations of four cooccurring chaparral shrubs, Oecologia 70 (1986) 527-535.

[10] Davis M.A., Wrage K.J., Reich P.B., Tjoelker M.G., Schaeffer T., Muermann C., Survival, growth, and photosynthesis of tree seedlings competing with herbaceous vegetation along a waterlight-nitrogen gradient, Plant Ecol. 145 (1999) 341-350.

[11] Day M.E., Greenwood M.S., White A.S., Age-related changes in foliar morphology and physiology in red spruce and their influence on declining photosynthetic rates and productivity with tree age, Tree Physiol. 21 (2001) 1195-1204.
[12] De Lucia E.H., Schlesinger W.H., Resource-use efficiency and drought tolerance in adjacent Great Basin and Sierran plants, Ecology 72 (1991) 51-58.

[13] De Lucia E.H., Schlesinger W.H., Billings W.D., Water relations and the maintenance of Sierran conifers on hydrothermally altered rock, Ecology 69 (1988) 303-311.

[14] Donovan L.A., Ehleringer J.R., Ecophysiological differences among juvenile and reproductive plants of several woody species, Oecologia 86 (1991) 594-597.

[15] Donovan L.A., Ehleringer J.R., Contrasting water-use patterns among size and life-history classes of a semi-arid shrub, Funct. Ecol. 6 (1992) 482-488.

[16] Donovan L.A., Pappert R.A., Ecophysiological differences among growth stages of Quercus laevis in a sandhill oak community, J. Torrey Bot. Soc. 125 (1998) 3-10.

[17] Epron D., Dreyer E., Picon C., Guehl J.M., Relationship between $\mathrm{CO}_{2}$ dependent $\mathrm{O}_{2}$ evolution and photosystem II activity in oak (Quercus petraea) trees grown in the field and in seedlings grown in ambient or elevated $\mathrm{CO}_{2}$, Tree Physiol. 14 (1994) 725-733.

[18] Field C., Mooney H.A., The photosynthesis-nitrogen relationship in wild plants, in: Givnish T.J. (Ed.), On the economy of plant form and function, Cambridge University Press, Cambridge, 1986, pp. 25-55.

[19] Field C., Merino J., Mooney H.A., Compromises between water use efficiency and nitrogen use efficiency in five species of California evergreens, Oecologia 60 (1983) 384-389.

[20] Kozlowski T.T., Kramer P.J., Pallardy S.G., The Physiological Ecology of Woody Plants, Academic Press, New York, 1991.

[21] Mediavilla S., Escudero A., Heilmeier H., Internal leaf anatomy and photosynthetic resource-use efficiency: interespecific and intraspecific comparisons, Tree Physiol. 21 (2001) 251-259.

[22]Mitrakos K.A., A theory for Mediterranean plant life, Acta Oecol. 1 (1980) 245-252.

[23] Poorter H., Evans J.R., Photosynthetic nitrogen-use efficiency of species that differ inherently in specific leaf area, Oecologia 116 (1998) 26-37.

[24] Reich P.B., Variation among plant species in leaf turnover rates and associated traits: implications for growth at all life stages, in: Lambers H., Poorter H., Van Vuuren M.M.I. (Eds.), Inherent variation in plant growth. Physiological mechanisms and ecological consequences, Backhuys Publishers, Leiden, The Netherlands, 1998, pp. 467-487.

[25] Reich P.B., Walters M.B., Ellsworth D.S., Leaf life span in relation to leaf, plant, and stand characteristics among diverse ecosystems, Ecol. Monogr. 62 (1992) 365-392.

[26] Reich P.B., Walters M.B., Ellsworth D.S., Uhl C., Photosynthesisnitrogen relations in Amazonian tree species. I. Patterns among species and communities, Oecologia 97 (1994) 62-72.

[27] Reich P.B., Ellsworth D.S., Walters M.B., Vose J.M., Gresham C., Volin J.C., Bowman W.D., Generality of leaf trait relationships: A test across six biomes, Ecology 80 (1999) 1955-1969.

[28] Thomas S.C., Winner W.E., Photosynthetic differences between saplings and adult trees: an integration of field results by metaanalysis, Tree Physiol. 22 (2002) 117-127.

[29] Tutin T.G., Heywood V.H., Burges N.A., Valentine D.H., Walters S.M., Webb D.A., (Eds.), Flora Europaea, Cambridge, University Press, London, 1964.

[30] Weaver J.E., Kramer J., Root system of Quercus macrocarpa in relation to the invasion of prairie, Bot. Gaz. 94 (1932) 51-85.

[31] Weltzin J.F., McPherson G.R., Spatial and temporal soil moisture resource partitioning by trees and grasses in a temperate savanna, Arizona, USA, Oecologia 112 (1997) 154-164.

[32] Wilson T.B., Witkowski E.T.F., Water requeriments for germination and early seedling establishment in four African savanna plant species, J. Arid Environ. 38 (1998) 541-550. 